\title{
Researching Feminine Professions: Reflections on Infant Schooling
}

\author{
Benjamin Zufiaurre (Corresponding author) \\ Public University of Navarra, Spain. E-mail: zufiaurre@unavarra.es
}

Maider Perez de Villarreal

Public University of Navarra, Spain. E-mail: maider.perezdevillarreal@unavarra.es

Received: December 20, 2013 Accepted: February 7, 2014 Published: February 28, 2014

doi:10.5296/jet.v1i2.5163 URL: http://dx.doi.org/10.5296/jet.v1i2.5163

\begin{abstract}
Over the last three decades in Europe, the field of "Gender and Education" and its development, has moved from investigating ways in which schools are to minimize gender inequality, to become a theoretical and empirical field of research. However, the disparities between men and women continue to exist and even increase in times of crisis. That is why to reference the paths towards equality in male and/or feminine professions, we are forced to weigh up salaries, social esteem, prestige, and others. And this is especially important when dealing with men and women sharing public and private spheres of life. In Infant schooling, and with Infant school teachers, to put it as an example, there is a need to balance child rearing and educating, or put it otherwise, the role of women as teachers, nurses and care keepers (Zufiaurre, Pellejero, 2000).

In the paper, we refer to Infant schooling as a school stage, to Infant teachers as "valued devalued" professionals, to the dimensions of care as integrated in modern colonial societies modeled by relations of dominion and dominance. We refer to Infant Schooling for historical and contemporary reasons. At this school stage, the stereotypes are not fixed, neither gender heritage. They are created. Infant school situations can be easily reversed, and Infant school teachers are to be reputable to contribute to changes in society.
\end{abstract}

Keywords: gender and education, feminine professions, infant school, professional development, stereotypes, sexism 


\section{Feminisms: Research and Practice}

Research on feminism, and/or academic feminism, is mostly concentrated today on big issues related to violence, inequality, and similar aspects (Moran, 2011), by using sociological research, cultural studies, and /or social sciences related issues. Feminism research, does not engage so much with the everyday life of ordinary women and their concerns. To re-turn it to the world of practitioners, to everyday issues and concerns, and to engage in the struggle for equality, is something which should be considered a challenge today. At the level of Infant schooling it can for instance be about issues such as girly things and boy things or about a bunny girl and a bunny boy.

It could be said that the field of "Gender and Education", expanded to all spheres of life and all fields of research, has in a way missed the opportunity to forge a discipline to embrace practitioners and academics, practice and theory, inclusiveness and permeability, consciousness and action ( (Weiner, 2012, p.3). Gender studies have moved to addiction to theory while research about changing practices has been left aside. This means that, while feminist thought has expanded, and while policy making on "gender issues" has expanded for overall democratic growing (Zufiaurre, Pellejero \& Weiner, 2010, p.401-403), feminist activism has become secondary (Hooks, 1989). And this is a situation which is being reflected in the so called "feminine professions" and, in our case, in Infant schools and around Infant school teaching.

And the question which opens here is if Infant school teaching is, and/or has been, a "feminine profession" because it has always, or mostly, been in the hands of women as a consequence of western world social stratification of labor (Apple, 1986) which supports that child rearing and motherhood is a professional world for women. Is it devalued as a profession because (just) women get access to it?. Is it a historically devalued profession because men do not have access to this professional field? In the world of "gender research", these are open questions, and this research cannot be developed if we leave aside what really happens with Infant school teachers, Infant educational research, Infants rearing and protecting. This cannot be done without analyzing as parallel why this stage is important as an inversion in human and social capital to develop early learning strategies, for socialization, for progress, for democratic development, and to prepare future intellectuals and citizens of the world.

As usually happens in situations in which one or another movement gets an important symbolic power, apparently successful for one or another circumstance, the symbolic power can be easy to get, more difficult to use, and easy to lose. Research on "gender and education", has ran a path forward, but if practitioners and academics do not find a joint space, if theory is not accompanied by guided practices, research on "gender and education" will not be successful. That is why, to clarify the state of the art in "gender studies" in order to dismantle the modern gendered biased order is, and will be, always relevant. But this is not enough. When changing attitudes related to discrimination on the basis of gender, practical clarifications and realities are present. Research on, or, related to practice, leads to better results than reflections on issues, which are important, but difficult to grasp. Knowledge and 
theory are important, but consciousness and action get further on (Weiner, 2012, p.4).

"Gender research" is, at least in Europe, and in the western world (Zufiaurre, et al., 2010), a flourishing field of research which pushes to improvement and to social changes from gender perspectives. But this, evidently, can move otherwise and can also move backwards. What true, is that any movement with aspirations of change, is to be rooted. To reduce the gap between theorizing and practical issues, activism is most important (Maguire, 2006), but positive intervention necessary.

It is at this point we can make a difference between the symbolic and the material power to differentiate between policy statements, interpretations in practice and outcomes. "Symbolic" refers to policies lacking defined measures, whereas "material" policies contain measures aimed at policy implementation and change. The aspirations emanating from policy legislation and their visible discursive and material implications are different.

No feminist analysis can at this point be neutral. Gender is to be used as a lens through which to conceptualize the policy apparatus that maintains and breeds male oriented systems of perceptions about reality. For one or another reason, women as professionals, work twice, paid and unpaid, care is not socially considered, women abilities at work: sharing and cooperating, their contribution to the work market, are not especially valued. All at the same time, women salaries are lower and the work market is biased from gender perspectives. And this is even worst in difficult situations and in times of crisis. Penetrating governance from gender perspectives can be gaining acceptance, but policy advances can easily be reversed when resources become scarce, or when the leading aims change for one or another reason.

\section{Infant Schools: Learning Territories to Learn About Gender Stereotypes}

Early experiences in the $19^{\text {th }}$ and $20^{\text {th, }}$ in Infant and Elementary Education developed on the assumption of education as community development. This move, widely known for the $2^{\text {nd }}$ half of the $20^{\text {th }}$ as " cities for children", has been conducted in the experiments conducted as a democratic response to fascism after world war $2^{\text {nd }}$ in Reggio Emilia (VV.AA., 1990 a), Torino (Alfieri, 1990), and Bologna (Frabboni, 1984). The international network for "cities for education", and "educational resources in cities" (VV.AA., 1990 b) in 1980's, followed that early move in Italy. The challenge, to humanize what under globalization is getting lost.

The First International Conference on cities for education was held in 1990 in Barcelona hosted by the municipality, the Council of Europe, UNESCO, and others. 46 cities from 20 countries participated. Since, this network has grown, and the driving force has been the belief in the transforming power of Infant education. But equally, the use of cities as laboratories for learning to live together, as spaces open to conviviality, dialogue and tolerance, and as spaces where to teach and learn to promote democratic knowledge and social cohesion. As Loris Malaguzzi, in Hoyuelos (2001, p.145-147) maintains: "schools in harmony with culture and the new forms of scientific questioning, have great options to contribute to the development of human wisdom. For this we have to leave aside the old world of programs of study to just repeat knowledge". "And here, teachers are to guarantee method, how to proceed in discussions, how to deal with interest, motivation, ideas, 
participation" (Hoyuelos, ibib, p.563-564).

Following Lipman (1997) and Tonucci (1990), this move pre-supposes: that *"children know and adults are to help them to integrate cognitive, social, emotional and motor knowledge"; that * "children are to build their knowledge through enquiry, reflection, reasoning, participation and constructive judgment"; that *"knowledge about the world is ambiguous, divergent and mysterious; that *"knowledge is juxtaposed"; and that *it is therefore hard to structure it into subject matters, as it is ever changing, it multiplies, and is built up over time, it is universal and particular to groups and their cultures".

The Infant School addressed to children from birth to up to six / eight years of age, takes the form of a broad-based educational community where children and adults learn and share education in an uninterrupted succession of exchanges. Rinaldi (1998) describes it as a school in which children recognize and build their rights, where they can be respected and valued for their own identity, uniqueness and difference. This Infant school is to provide answers to the social changes that demand relevant sets of knowledge, skills and values that work well in a diverse society. And if we consider that school is a place where children, whatever their sex, race, class or creed is, integrate into the community proving to be responsible, active, critical, thoughtful and supportive individuals, capable of interacting in a societal context which otherwise characterizes by discord, homogeneity and resistance to change, something is to be done to defend these schools and to protect the professionals involved.

In the words of Molina (1988, p.31), Infant school is to be considered "a broad-based educational community with its own means and resources, equipped not to substitute the educational roles of other members or institutions within the community (family, friends, neighbourhood', social services, municipal authorities, health departments...), but rather to collaborate with them in guaranteeing an education for all.

Infant education, following these premises: learning territories to pre-form convivial schools in cities for children to learn to be human, is supported on the basis that early childhood has its own identity, and that the Infant School gets a sense and a meaning to provide a high quality educational service. Implementing Infant services depends on availability of resources. But implementation pushes to some changes, to say, the realignment of curricular components, change policy organization, behavioral norms and guidelines, availability of school spaces, a time for planning a range of activities, establishing good relations with the community, settling together professionals which have relevant theoretical and practical training... To implement this type of schools, demands commitment on the part of the entire educational community, and this includes teaching teams, the educational administration, the organization and the families.

\section{Infant Schooling for Social Change}

Scientific and technological innovation is pushing today for social changes. And this has clear implications in the way we think about, and construct, Infant schooling for the twenty first century. To do this, we have to look anew at how we understand knowledge, and also, we 
have to look at what theories are emerging from research in brain functioning and knowledge derived from developmental sciences.

Knowledge and understanding: With respect to knowledge and understanding, we come up with a widespread trans-disciplinary movement which is pushing towards an ecological conception of knowledge, and therefore of education. This current thinking rejects any attempt to encase reality in a simplified framework, or split it into disciplines using a specific sectorial approach to knowledge. It embraces multiformity and complexity, and honors the coexistence of scientific and cultural developments (Bronfenbrener, 1987). According to this, we should approach knowledge, and childhood, not in a parceled specific way, not in isolated compartments. We are forced to reformulate the human image as holistic and ecological. This position can lead us to understand human interaction and pushes us to consider the environment as a mobile pattern of links in which the human participates, not dominates.

The nature of the brain functions: Brain research is a genetically programmed structure in constant evolution, or involution, a mobile structure within a system of nerve cells, and depends from environmental factors (Zeki, 1995). This means that human development is to be considered in its interdependence with environmental and educational conditionings. It is through exchange with adults, peers, and via active participation, that children and adults interact, and that the different roles evolve in a broad and varied range of situations in which development takes place. The organization of the brain has an influence in how education is to be envisaged, or how the emotional environment is to be integrated, and how this modifies the way in which information is and can be processed. And even when the complexity of our brain exceeds our capacity to predict how it works (Gardner, 2001), a general theory of the brain is envisaged today. And whatever emerges from such theorizing is to have an impact on how we think about knowledge construction and how we construct Infant schooling.

The developmental sciences: The developmental sciences lead today to consider human beings in their plasticity as open learners in the early years of life. To consider early years of schooling seems to be the most compelling argument for education, and this is justified for the successful development of language, cognition, control and balance of the emotions, psychomotor skills and socialization in an environment rich in valid stimuli (Mora, 2001). An important part of these rich stimuli derives from the increasing diversity of our societies and communities. And diversity is the kind of educational environment that will allow children, through interaction with their peers, their teachers and other adults, and through participation in different life experiences and situations, to develop their capacities when acquiring knowledge, skills, abilities and values, while recognizing and identifying which conditions will enhance their later learning, development and socialization (Maturana \& Varela, 1999). For a child to be socialized as a member of a cultural group in a human community, assistance is required, and this is not something for which individuals are genetically programmed. Active Infant Schooling can contribute to the socialization processes in culturally, ethnically and religiously diverse communities.

Infant schooling and social inclusion: It is in Infant schools that we can find the path that leads towards social integration. In Infant Schools, children can learn to interact early in their 
lives, families are able to meet each other and get involved in collaborative and participatory endeavors and activities. In Infant schools we can guarantee in the wider sense the development of a common approach towards cultural diversity for all to attend to individual needs when schooled (Warnock, 1989) while opening streaming mechanisms for socially disadvantaged pupils. And for this, available options are: to provide measures of school guidance, supervision and mentorship, while adapting school structures and curriculum contents to diversity. That is how teachers can assist students in their academic progress, and in other social, personal and moral dimensions of their development.

\subsection{Infant Schooling: A Feminine Profession}

Ruddick (1989, p.40) considers a mother as "a person" who takes responsibility for children's' lives. For mothers, providing child care is a significant part of her working life. But as Ruddick (ibid) sustains, both men and women can be mothers, even when the powers of mothers are limited by the "gaze of others". To establish similarities with the sense and meaning of the so called "feminine professions", and to analyze how Infant school professionals have to find a balance for further previsions in this early school stage, is then important. Are these professions devalued because women have easy access to them?. Or do women have access to these professions once these professions are socially devalued?.

The term: feminine profession, and / or the gender(ed) classification of labour, is used to indicate whether a profession is classified as female or male. The very ability of women to conceive, bear and breastfeed children, together with other qualities attributed culturally (affection, gentleness, understanding, patience, sacrifice...), has resulted in women being directly associated with child rearing, to the extent that the care, upbringing and early education of young children, has come to be considered a task inherent to the female sex.

Feminine professions in western societies, have several features in common: a vocational nuance of the work that functions as a "emotional mattress"; low status not applicable to the high responsibility of dealing with people with needs; and with difficulties associated at the emotional and experiential levels related to the status of working and not working, disenchantment with the low status and low participation, private and public spheres of life and work, women professionalization in decision making, etc. Affective dependency of women as workers is reflected by the contradictions which emerge when dealing with the relationship between working outside and domestic activities.

When we get to think on Infant schooling (1) as a feminine profession, we are forced to analyze why this is a feminine profession. And this is especially important when considering the aims of this school stage: to contribute to children's physical, mental, emotional, social and moral development. This represents, that Infant School teachers, have a heavy degree of responsibility, not only because of the far-reaching nature of their objective, but also because it is precisely during this stage in the child's life that the foundations of her/his psychological development are laid. Therefore, the educational provision for children of these ages is important for their development and for the development of the learning processes (Zufiaurre, Wilkinson \& Albertín, 2013). 
In modern societies, the division of labor: male - female, has been historically characterized as something tied, or better, related to the public and private spheres of life. In modern societies, the professions related to care, compromised with social services, or bothered about healthy development, fruitful socialization, and others, are not considered productive. As a consequence, there is not much need to sponsor and to protect them for a better future. It is a context in which private enterprising claims to do it better for less. Fragmentation and privatization when public expenses are scarce are just a sequence (Hamilton \& Zufiaurre, 2013).

\subsection{Child Rearing and Care Define Infant Teachers' Professional Labour}

Caring to human's supported on evidence and research, defines the educational role of Infant School teachers. If we look at this from the lens of Infant Schooling as a profession, the tendency is not to consider Infant schooling as a true stage of education, since playing is what basically children do at this stage. Therefore, the work involved in teaching in Infant schooling, is not considered to involve any particular complexity, and/or importance, or at least not as much as other stages of education. When thinking about what teachers do in the first stage of Infant Education, the persisting tendency is to look after small children while their mothers are at work. The subsequent perception is that a female teacher will cover better the needs of the kids than a male teacher. And women employed at this stage, are not considered true educators, but mother substitutes.

It is clear that as a consequence of modern ways of development, the voices of care and the circumstances in which schooling is organized are differently shaped if it is the case of women or men. Today women have had access to education and to the work market, and consequently, have got access to a different level, and / or stage, in their personal and professional development. Both women and men share evolution, share life, and confront the future together, and at this point education has a role to play. But male and women are not considered equally, and this is especially evidenced when dealing with "feminine professions". It will then be important to take it into account as a condition of evolution and as a condition for democratic development (Zufiaurre \& Pellejero, 2000).

The paradox arises however from the fact that these first stages of the child's life are important, because the nervous system is malleable at its most, and because early experiences are crucial for children`s development. Early ages are a delicate and difficult period which requires extra tact, finer judgment and more expert knowledge. Furthermore, the environment in which early socialization takes place, is of utmost importance for the future, since the first years of life are of enormous importance in shaping whole, well-balanced individuals, and since this is the most intense period of development for the brain. To supply positive references for boys and girls and their future growth and development, it is important to provide models of female and male teachers at the time. According to Pellejero (2002), whether an occupation is considered female, or male, has little to do with its inherent characteristics. It has more to do, and is much more related, to the number of persons of either sex employed in the profession. When the majority of those employed in a certain profession are of the same sex, there is a tendency to think that members of that sex are the 
best people for the job (Alvesson and Due Billing, 1997). In other words, there is a tendency to consider that a particular sex, because of its very characteristics (gender codes attributed to it by society), is most suitable and the best prepared to undertake this occupation.

Child rearing has historically been considered the task of parents, and even more, of mums. It was with the advent of the industrial society, which brought several social changes including adults absence from home, smaller households, and women's entry to the work market, that clear decisions were taken to make early childhood care and education a joint responsibility of the State and the families. It was in this context of development, that the first early childhood care facilities were introduced conceived on a similar line as the orphanages and children's hospitals that had preceded. These were charitable welfare institutions, intended for the custody of children who had been orphaned, or left without adult supervision, for one or another reason. If we think on schools for early aged boys and girls, it is because both parents had to work.

Geographical and historical considerations aside, the social image of childhood in every culture and every past era, has been one of bareness, neediness, helplessness, with no recognized autonomy or identity. Thus a contradictory function of Infant education developed. On the one hand, attending to the educational needs during the earliest and most crucial stage of children's development. On the other, being primarily custodial by caring and protecting young children, and, at most, keeping them entertained (Bowlby, 1952).

Early educationalists: end $19^{\text {th, }}$ beginning $20^{\text {th, }}$ such as Froebel, Montessori, Decroly, the Agazzi sisters, and others, argued in favor of an early educational function of Infant School. Thanks to their efforts and foresight, there are numerous examples of thoroughly valid experiments of schooling that have led to successful learning and development outcomes in children. Yet the contradiction lingers on. But the view of the child as having her/his own identity is gaining credence. Family patterns change, single, adult, no male figures... Children are no longer seen as just adults in the making, needy of guidance and protection, but as individuals with rights. Children's needs and rights have become the focus of attention and provide a foundation to underpin a rationale for providing Infant schooling for all children.

\subsection{Motherhood and Professional Labor}

Women, for various reasons, have traditionally been considered more suitable for taking care of children and for taking responsibility for their care and education. Motherhood is here one of the more compelling reasons as women`s ability to conceive, bear and nurse children and provide mothering, has linked women inexorably to children. Motherhood which usually takes place within the home requires no special training. The particular socialization process that women undergo, however, leaves them with a series of skills suited to the care and education of young children, and thus places them at an advantage over men, making them the best candidates for the profession (Zufiaurre \& Pellejero, 2000). Nevertheless, the possession of such skills is not acknowledge as a qualification in the labour market, nor is their value recognized because these are skills that are acquired in the home, that is, in a sphere that is undervalued, the female sphere (Carrasco, 1996). As Cristina Carrasco (ibid) points out, gains and losses in job status usually fit with changes in the numbers of men and 
women employed in the profession. This same author reports, moreover, that rises and falls in job status follow a kind of vicious circle in which women's work is continually undervalued, both at the productive, and domestic level.

One of the features in patriarchal societies is the gender(ed) division of labour. There are certain professions that are woman-dominated (female professions) and others that are monopolized by men (male professions). Attempts have been made to justify this state of affairs with allegations to the effect that men and women have preferences for different types of job; preferences that are borne out the simple fact that their interests are different. The true reasons, however, are more deeply rooted. Alvesson \& Due Billing (1997) argue that the reason why men and women take on different roles in life lies in the socialization processes to which they have each been subjected, the effects of which emerge in the behavior and job preferences that they display later in life.

The reluctance of men to enter female-dominated professions, for example, is, according to Alvesson \& Due Billing (1997), a consequence not only of the low salaries and low social prestige associated with these professions. The fact that they are classed as "female professions" is of great significance. When it comes to classifying a job as male or female, therefore, the issue revolves not so much around the nature of the job itself, as the number of people of either gender who perform it, with the result that professions previously classed as male (administrative work, for example) may now be considered female, and others traditionally viewed as being female (the midwives of old), have been admitted to the category of male occupations (gynaecologists), for example.

According to Alvesson \& Due Billing (1997), it is rarely the intrinsic nature of the job that determines its gender classification. It is simply that when an occupation is carried out exclusively, or predominantly, by one of the sexes, there is a tendency to think that people of that sex must be the most suitable for the job. At the labour market, the assignation of tasks in our patriarchal societies depends on a differentiation between masculine and feminine qualities, which in addition, are considered to be mutually exclusive. In other words, a person's affectionate trait (a quality viewed as being feminine) for example, appears to be in conflict with any possible rational trait (masculine attribute).

Thus women, the female element, are from the very start relegated to a second place, and the predominance of masculinity over feminity is a constant cross-culture factor in western societies. In consequence, the characteristics considered as being masculine (self-confidence, independence, reasoning, authority, objectivity...) have a greater value, whilst the qualities considered as being feminine (insecurity, dependence, emotion, passivity, subjectivity...) are of inferior value. Men are placed, a priori, in a privileged position which allows them to remain superior to and in control of women. To perpetuate the patriarchy is an aim. It is so that gender, as a basic principle of social organization, appears to be a key factor when it comes to valuing any profession. And considering that Infant Teaching is a strongly female profession, therefore, it could indeed be said that this very fact has a negative influence in its social status.

In the survey "Women, Health and Quality of Life" mentioned (1), a large proportion of 
women Infant teachers interviewed did not appear to see any connection between theirs being a female profession and the degree of social status they enjoyed. Nevertheless, the vast majority $(84,2 \%)$ considered important that girls and boys up to 6 years of age should be provided with both female and male role models in Infant classrooms (2). It should be understood that if the presence of male role models in Infant Schools was considered important because only by providing both models any progress towards equality can be made. In other words, if small boys and girls see from early in life, that men and women perform the same tasks indistinctly, it will be easier to break away with the gender division of labor both in the public and private sphere. And thus, it will be easier to achieve a greater equality and a more productive, while democratic socialization.

But there may be another angle from which to interpret this. It might be considered that indeed slightly more than half of all women teachers do not consider the social status of their profession to be negatively affected by the fact that it is classed as a female job (Amorós, 1993). At the same time, however, the vast majority consider the presence of male role models to be beneficial, because they understand that the presence of both gender models enables the transmission of values: more fully and more fairly. In other words, women teachers appear to think that, since the vast majority of Infant School teachers are women; it is the female role model that is being presented and feminine values that are being transmitted.

This being the case, the integration of more men teachers ensures the presence of the male role model to redress this unbalance. If boys and girls are offered both female and male role models, they can receive both sets of values as a part of a natural, balanced process. But this is a much less encouraging conclusion because it suggests a serious lack of awareness among women teachers based on the fact that that they are the transmitters of the dominant, male values. Women teachers unconsciously repeat sexist stereotypes, because a major part of the education they receive, conditions their view of the world and prepares them for passing on the dominant values both inside and outside the family (Freud, 1993). This lack of awareness constitutes an obstacle to achieve equality, stopping them from finding a new place in society on an equal basis with men, as their peers.

\section{Gender Roles can be Reversed: Experiences in Infant Schooling}

From the moment of birth, children are active beings, able to respond to the stimuli they receive and to react to the actions of those who share the world in which they interrelate. Children are able to send out and receive signals of social, emotional and cognitive interaction; they are able to receive and express affection and emotion and to bond with others (Zufiaurre, Wilkinson, \& Albertín, 2013).

But children are not born gendered. The roles they live and assume being educated and/or socialized, as boys or girls, determine how they identify themselves in front of life and which attitude they are to develop in their future development. Children assume their gendered roles in their family, school and social stereotyped atmosphere. Children grow in a world of pre-formed regulations, but in a world of unequal practices when they get familiar with different roles, attitudes and values regarding to gender. Their father, mother, teacher, 
relatives and friends, project their expectations towards what boys and girls have to do in their future, how they are to identify and grow. (Luke, 1996; Gilligan, 1982; Gilligan \& Wiggins, 1987)

The clothes and colors they wear, the plays and toys they have access to, the way they speak, behave, the shared individualistic and/or self-centered values boys and girls have to assume ..., determine boys and girls patterns of life beveled. Boys and girls are caressed differently, and both, in a way, are emotionally neglected. In their process of development, the others speak to them differently. And as they grow, they perceive the sex and gender biased images in the media.

Following Connell (1987) gender difference (in terms for instance of individual behavior, attitudes, material conditions), feminities and masculinities, are structurally created, refined and reproduced at different levels and in different contexts. This often culminates in discriminating practices and stereotyped views of girls and women as more tied to their biology, nature and the private sphere of the home, than their male equivalents, boys and men, who are seen as more suited to the sciences, abstract thinking, and the public sphere of paid work, industry and politics.

In education we cannot claim to be neutral, but rather use gender as a lens through which to conceptualize and to dismantle conventional and limiting definitions and stereotypes (Marshall,1997, p.3). And to change for better, we have to deep on wider cultural factors, on how policy and attitudes are built, and in whose interests. And the question opened here is: is it possible to emphasize equal development for boys and girls through education?

We understand this is possible and to illustrate our point of view, we are going to introduce an example of many situations working with teachers in some Infant schools which give options to illuminate positive intervention from a balanced gender positioning:

Situation 1: In a Classroom with 5 to 6 year old boys and girls - not complete rural school.

End of course. It is a very hot day.

A boy and a girl sit together, dressed with short-leave T-shirt. They have the following conversation:

C. boy: "I have more black hair on my arm than you".

V. girl: "No, we both have the same".

C.: "But when I get older, I will have more, not you. You will screw up".

V.: She gets thoughtful and a little later she replies. "But I will have babies and you will not be able to".

C.: "But I will go to work to a company and you will not".

V.: "But that does not bother me, because I will be a doctor. Mothers can also go to work outside" (she is referring to the canning factory at the village). 
Teacher attitude:

After the girl's intervention, the teacher resumes the conversation and participates, dealing with the issue of biological and work differences related to gender stereotypes.

The teacher insists in the biological differences at work, if there are.

- What are the differences and the similarities between boys and girls?

- When boys and girls get older will there be the same, less or more differences?

There is an open discussion about differences between both sexes. Differences, if there are, should not imply a kind of gender supremacy of one over another.

This discussion continues with a debate about the underlying cultural burden and sexual stereotypes assigned to the different jobs related to gender.

Situation 2: In a Classroom with 5 to 6 year old boys and girls - a city school (3 to 12 years)

J. boy: "I do not want to play with the cradle, or dolls bottle feeding, because it is a girly thing".

J.J. boy: "When we play mummies and daddies, daddies also look after the dolls".

D. boy: "That's it. My uncle bottle feeds my cousin and cuddles her because she is a baby."

P. girl: "Dads bottle feed, but do not nurse, only mums nurse, but it does not matter, dads also love us and take care of us."

The teacher: Stops the conversation and reaps what the girl just said.

\section{Teacher attitude:}

We are going to open a discussion about these terms: "to be a girl thing" or a "boy thing" and which implications this has.

From what the kids say different conversations can be exploited to realize and become aware about family and social attitudes towards the boys and the girls.

The aim is to assess positive behaviours in men to break gendered stereotypes and to identify positive attitudes and pleasure when not following the stereotypes.

Situation 3: In an Infant school classroom with $2 \& 3$ year old boys and girls - in different play situations. There are seven 2 to 3 years old boys and girls playing 
They are reading a story in a comfortable way at the story-corner. The teacher gets near them and asks: "Who is going to read the story for all of us?". Three boys and one girl raise their hands.

The teacher to the girl : “A. you can start yourself”. The girl reads:” It is a little bear in bed with his bunny boy".

I. A first boy: "No, it is not a bunny boy, it is a bunny girl".

The teacher: "A. says, it is a bunny boy, isn't it?". She looks at the group. "No, no", I. say.

The teacher: "Let's see, why does I. say it is a bunny girl, and A., it is a bunny boy?".

I. says: "Do you know, our friend M. my cousin? In her house there is a bunny girl in the bathtub".

A.:" Ok! The one at your aunt's house is a girl, but this one is a boy", says A.. book).

I.: "You know it is not, it is not pink and it is not the same" (he points at the story boy".

The teacher: She asks to the group of boys and girls and they answer "it is a bunny dress".

D. a second boy: "Your aunt I. has a bunny girl, but this is a bunny boy who has a pink

\section{Teacher attitude:}

After the discussion, the teacher resumes the conversation and shares clarifications about gender roles and stereotyped differences when relating to feminine and masculine different plays and colors ....

She also insists in working about sexual gendered differences.

She exploits the situations to promote cooperation and mutual understanding.

\section{Concluding Comments}

At the level of Infant education and Infant Schooling, boys and girls are all considered equal individuals from the earliest age. All men and women, boys and girls, have the right to be educated. Education enables them to achieve the full deployment of their (his or her) capacities. In Infant education, however, there are points at which different problems converge: class, gender and ethnic relations, institutional constraints, etc. Each child comes into the school with an own and unique unrepeatable history. It is through interaction, exchange and comprehension of the children attitudes and actions, that the possibility to communicate on equal terms for children and adults emerges. The children's way of life, their physical, nutritional and hygienic needs, their emotions, deprivations, beliefs, fears and 
sorrows, can be recognized and addressed in a positive school environment. The mutual understanding and recognition of the specific nature of each individual, opens up a wide range of avenues and possibilities of intervention to address positively to the children, their families and the communities as whole.

Integration is not easy to achieve when different aspects related to of the diverse personal, social, moral, cultural aspects are to be balanced. When differences merge in a whole open frame, the unfamiliar can be accepted on equal terms with the familiar, and each member can find an opportunity to construct her/his own identity in harmony with the rest. And this must be done at least if society is to work for the good of all its members. There is a current demand for schools to contribute to redress and mitigate a strong social tendency towards classification and exclusion to enhance disparities has no future, and with high quality Infant schools it is possible to prepare open minded democratic citizens for the future.

But how can we work on redefining Infant schooling when most Infant school teachers involved, are just women?. ¿Does society trust women to educate the children and the future adults for the $21^{\text {st }}$ century?. In which sense?. Under which responsibilities and work functions?. ¿Can women as professionals share their personal and professional deal when educating society and the children?. Infant school is and has been important for a better future in modern societies. But in a context of post-modern contradictions, unemployment, reducing salaries, and diminishing the sense and the meaning of the public function of schooling, modern disparities between mind and body, theory and practice, cannot be sustained anymore, and gender, class, race, religion, identities... disparities, have to be balanced otherwise. Certainly Infant school teachers have to do their best to improve their social esteem, to give a value to the work they do. In times when welfare and social services are challenged, we have to look back to how children progress in their early ages, when sharing school spaces, when researching, socializing and stimulating together. And it is through Infant school education that we can prepare children for equality to develop human rights and democratic values.

\section{Notes}

1. The Research project: 'Women, Health and Quality of life', funded by the Community of Navarra (Spain) (Department of Social Welfare) during the years 1993 to 1997. Infant school teachers and nurses were interviewed, and lot of information was gathered to be used under explicit consent. Since, the Research Group EDUCATION, SOCIAL AND PROFESSIONAL DEVELOPMENT in the Public University of Navarra, has continued working and developing experiences on gender and inclusion in schools. At their initial stages, the Group participated in a E.U. funded a TENET research project from 1989 till 1991, to deep on how the context to develop coeducation programs was at different school levels in Navarra (Spain). This project, outlined ways to intervene at schools which have continued over the time specifically in Infant and Primary Education. (see Publications, Zufiaurre \& Pellejero, 2000; Zufiaurre \& Albertín, 2009; Zufiaurre, Pellejero \& Weiner, 2010; Zufiaurre, Wilkinson, \& Albertin, 2013, plus papers in Conferences (AERA, ECER and others).

2. The school stage 3 to 6 years: Infant Schooling, although not compulsory in Spain, is integrated as a joint stage with Primary: 6 to 12 years, building full schools 3 to 12 years all 
over the country. There is an extra offer of infant school 0 to 3 years, linked to learning and care while organized in different school buildings and usually with a different school administration.

\section{References.}

Alfieri, F. (1990). La ciudad de los niños. Los recursos de la ciudad. In VV.AA.: La ciudad Educadora (Cities for Education). Barcelona: Documents of the International Conference.

Apple, M. (1986). Teachers and Texts: A politic economy of class and gender relations in education. London. Routledge and Kegan Paul.

Alvesson, M., \& Due Billing, Y. (1997). Gender and Organizations. London: Sage.

Amorós, C. et al. (1993). Programa de sensibilización social acerca de la igualdad de oportunidades en hombres y mujeres. (Program to raise awareness about Equality of opportunities for men and women). Pamplona: Subdirección de la Mujer. Gobierno de Navarra.

Bowlby, J. (1952). Maternal care and mental health. London: World Health Organization.

Bronfenbrenner, U. (1987). La ecología del desarrollo humano (Ecology of human development). Barcelona: Paidós.

Carrasco, C. (1996). Presente y futuro del trabajo. Apuntes para una discusión no androcéntrica. In A. Rodríguez, B. Goñi, \& Maguregi (Eds.), El futuro del Trabajo. Reorganizar y repartir desde la perspectiva de las mujeres (The future of labor: Reorganizing and sharing from women 's perspectives) (pp. 19-46). Bilbao: Bakeaz / CDEM.

Connell, R. W. (1987). Gender and Power: Society, the Person and Sexual Politics. Stanford: Stanford University Press.

Frabboni, F. (1984). La educación del niño de 0 a 6 años (Education for children 0 to 6). Madrid: Cincel.

Freud, A. (1993). El yo y los mecanismos de defensa. (Myself and defense mechanisms) Barcelona: Paidós.

Gardner, H. (2001). La educación de la mente y el conocimiento de las disciplinas (Education of the mind and subjects knowledge). Barcelona: Paidós.

Gilligan, C. (1982). In A Different Voice. Cambridge, Mass: Harvard University Press.

Gilligan, C. and Wiggins, G. (1987). "The Origins of Morality in Early Childhood Relationships”. In J. Kaggan \& S. Lamb (Eds), The Emergence of Morality in Early Childhood (pp. 71-88). Chicago: University of Chicago Press. Hooks, B. (1989): 'Toward a Revolutionary Feminist Pedagogy`Talking Back: Thinking Feminist, Thinking Black. Boston: South End Press.

Hamilton, D., \& Zufiaurre, B. (2013). Blackboards and Bootstraps: Revisioning Education and Schooling. Rotterdam: Sense. 
Hoyuelos, A. (2001). El pensamiento y obra pedagógica de L. Malaguzzi y su repercusión en el la E.I. (Pedagogical mastery of L. Malaguzzi: Influence in Infant schooling) Pamplona: Doctoral Thesis, UPNA.

Kheel, M. (2008). Nature Ethics. New York, NY: Rowman \& Littlefield.

Lipman, M. (1997). Pensamiento complejo y educación (Complex thinking and education). Madrid: De la Torre.

Luke, C. (coord) (1996). Feminisms and Pedagogies of Everyday life, State University of New York. (Spanish edition, 2000) Madrid: Morata.

Maguire, P. (2006). Uneven Ground: Feminisms and Action Resarch. In P. Reason \& H. Bradbury (Eds.): Handbook of Action Research (p.59-69). London: Sage.

Marshall, C. (1997). Dismantling and reconstructing policy analysis. In C. Marshall (Eds). Feminist critical policy analysis: A perspective for primary and secondary schooling (pp. 1-40). London: Falmer Press.

Maturana, H., \& Varela, F. (1999). El árbol del conocimiento. Las bases biológicas del conocimiento humano. (The tree of knowledge. The biological frame for human knowledge). Barcelona: Debate.

Molina, L., \& Jimenez, N. (1989). La escuela Infantil: Lugar de acción y participación (Infant school: A space to act and participate). Barcelona: LAIA.

Mora, F. (2001). El reloj de la sabiduría: Tiempos y espacios en el cerebro humano (The clock of wisdom: Time and space in human brain). Madrid: Alianza.

Moran, C. (2011). How to be a woman. London: Ebury Press.

Pellejero, L. (2002). Tesis doctoral: Valoración social de la educación infantil desde la perspectiva de género (The social recognition of infant education from a gender perspective) PhD European diss., Public University of Navarra - Umëa University.

Rinaldi, C. (1998). Los pensamientos que sustentan la acción educativa (Thoughts underlying educational actions). Barcelona: INFANCIA $\mathrm{n}^{\circ} 50$.

Ruddick, S. (1989). Maternal Thinking: Toward a Politics of Peace. New York, NY: Ballentine Books.

Tonucci, F. (1990). Enseñar o aprender? La escuela como investigación quince años después. (Teach or learn? Research on schools fifteen years later). Barcelona: Grao.

VV.AA. (1990 a / 1995). Escuelas Infantiles de Reggio Emilia: La inteligencia se consigue usándola (Reggio Emilia Schools: Intelligence is built by using it). Madrid-MEC: Morata.

VV.AA. (1990 b). La ciudad educadora (Cities for education). Barcelona: Document of the 1st. International Conference.

Warnock, M. (1989). A common policy for education. London: Oxford University Press. 
Weiner, G. (1994). Feminisms and Education: An Introduction. Buckingham: Open University Press.

Weiner, G. (2012). A dangerous addiction: Theory, Feminism and Education. Working Paper. Umeä and Sussex Universities.

Zeki, S. (1995). Una vision del cerebro (A perception of the Brain). Barcelona: Ariel.

Zufiaurre, B., \& Pellejero, M. L. (2000). Women Infant-school teachers in Spain: How does society and how do they consider their professional role. In Pedagogy, Culture and Society, $8(2)$, 207-218. London

Zufiaurre, B., \& Albertin, A. M. (2009). Playing games to interact and work with emotions in Infant / Elementary education. Journal of the International Society for Teacher Education, $13(2), 23-31$.

Zufiaurre, B., Pellejero, L., \& Weiner, G. (2010). Gender Equity and Education in Spain: Policy and Ideology. In Education Inquiry, 1(4), 399-414. Retrieved from www.use.umu.se/english/research/educationinquiry

Zufiaurre, B., Wilkinson, J., \& Albertin, A. M. (2013). Working with children's emotions through routines, play and games: Promoting emotional and social growth and shaping inclusive practices. In Journal of the International Society for Teacher Education - Education for Gross national happiness: Role of teacher, 17(1), 126-138.

\section{Copyright Disclaimer}

Copyright reserved by the author(s).

This article is an open-access article distributed under the terms and conditions of the Creative Commons Attribution license (http://creativecommons.org/licenses/by/3.0/). 